\title{
Studies of the first and second maxillipeds of the fiddler crab, Uca lactea
}

\section{Takao Yamaguchi and Rie Ogata}

\begin{abstract}
The number of setae on the merus of the first and second maxillipeds of the fiddler crab, Uca lactea (De Haan, 1835), was examined. The whole outer face of the first maxilliped is covered with numerous arrow-headed, slender setae. On the inner side of the second maxillipeds there are two kinds of spoontipped setae; short- and long-stalked. Adjacent to these, plumose setae grow on the proximal region. There were no statistically significant sexual differences in the number of setae on the first and the second maxillipeds by the sex. Also, no differences were found in the length and width of the two maxillipeds by sex. Male and female $U$. lactea are equipped with mouthparts that have the same size and function.
\end{abstract}

\section{Introduction}

The most characteristic feature of male fiddler crabs of genus $U c a$ is the presence of an enormously developed large cheliped in males. The large cheliped develops on either side. Fiddler crabs eat organic material, including diatoms and bacteria that are attached to the inorganic substratum granules. The large male cheliped is too large to scoop the substrate and is therefore, useless in feeding. Adult males only scoop the substratum with their minor cheliped. In the immature stages, the large cheliped is not differentiated (Yamaguchi, 1977) and males have two equal-sized small chelipeds that they use for feeding. Female fiddler crabs have two symmetrical small chelipeds and use both for feeding. It is an interesting problem to determine how adult males compensate for their disadvantage in feeding.

Crane (1941) examined the fiddler crabs of Central America and reported differences between species in the shape and density of the hairs (setae) on the merus of second maxillipeds. Altevogt (1955a, b) studied shape differences of spoon-shaped hairs between two fiddler crab species, $U$. annulipes (H. MilneEdwards, 1837) and $U$. marionis nitidus (=U. vocans (Linnaeus, 1758)) and found the diameter of the tips of the hairs increased with growth but the size difference between small and large individuals is relatively small. Miller (1961) examined the mouthparts of three fiddler crabs, U. pugilator (Bosc, 1802), Uca pugnax (Smith, 1870) and $U$. minax (LeConte, 1855). He found that in $U$. pugilator spoon-tipped hairs are most well developed. In $U$. pugnax, such hairs are developed to a lesser degree and in $U$. minax, the modification of spoon-tipped hairs is least. Ono $(1962,1965)$ studied the relationship between the distribution of ocypodid crabs and the characteristics of their habitats, such as soil texture, elevation, duration of exposure etc. $\mathrm{He}$ showed illustrations of the spoon-shaped hairs on the first and/or second maxillipeds of seven species, including $U$. lactea. He also presented illustrations and photographs of the second maxillipeds and classified setae by the shape of the spoonshaped tip. He recognized three types of setae in U. lactea; two on the first and one on the second maxillipeds. Ono (1965) showed that the density and shape of the setae on the maxillipeds of ocypodid crabs 
have a close relationship with the substrate. Crane (1975) presented illustrations of spoon-tipped setae of 15 species of $U c a$ and the figures of the merus of the second maxilliped of five species. However, the above mentioned authors did not investigate possible differences of mouthparts between the sexes.

Weissburg (1991) considered that females must possess characteristics which confer higher extraction efficiency at elevated scoop rates and examined the density of setae on the first and second maxillipeds in $U$. pugnax. He found statistically significant differences between males and females in the density of setae; females possessed 10 to $50 \%$ more setae per unit area.

The aim of the present study is to clarify possible sexual differences in the mouthparts of $U$. lactea. This crab is one of the two Uca species that occur on mainland Japan (Sakai, 1976). It lives in sandy-mud tidal flats located in protected inner bays or estuaries. Uca lactea forages near its burrow and possesses well developed spoon-tipped setae on the second maxillipeds, as does $U$. pugilator. We examined not only the sexual differences in setae number but also the relationship between the size of mouthparts and crab size.

\section{Materials and Methods}

Specimens of $U$. lactea were collected during 1970-1974 at Nagaura Island in Amakusa, Japan. They were obtained in the course of a study of population dynamics and were preserved in $75 \%$ ethanol. Numerous and various-sized setae grow on the first and second maxillipeds. Spoon-tipped setae grow on the merus of the second maxillipeds. The setae are small and short on the peripheral area, then gradually increase in size towards the centre. Moreover, there are two kinds of spoon-tipped setae; short-stalked and long-stalked. We soon understood that it was difficult to count correctly the number of setae or to know the density of setae by the method adopted by Weissburg (1991) who measured the density by the counting the setae found in $15 \times 15$ to $10 \times$ $40 \mu$ grids. The shift in size and gradual transition of the distribution of the two kinds of setae, prevented appropriate placing of grids and accurate setal counts. We found it easier to count the number of pores that appeared after the setae were removed. To remove the setae, the first and second maxillipeds of the right or left sides were carefully detached from the crabs and sonicated in $80 \%$ ethanol for one to three minutes. Sonication was repeated several times until most setae detached. Then the maxillipeds were dehydrated in graded series of ethanol and tbutyl alcohol. After transferring into $100 \%$ t-butyl alcohol, the mouthparts were freeze dried. After careful mounting under a stereo microscope on a small metal cylinder using double faced adhesive tape, the maxillipeds were coated with gold for 3 minutes. Coating was repeated 3 times. Observations were made using a JEOL-5400 Scanning Electron Microscope. The measurement of the maximum width of the spoon of setae was carried out under a light microscope equipped with an ocular micrometer. Crab size was measured across the maximum carapace width (CW).

\section{Results}

Distribution of setae on the first and second maxillipeds

Photographs of the outer side of the first and the inner side of the second maxillipeds are presented in Fig. 1. The merus of the first maxilliped is covered with numerous thin arrow-headed setae. In contrast, on the merus of the second maxilliped the setae occupy less than a half of the surface area. From the inner margin to the center, three kinds of setae arise on the second maxillipeds (Icely \& Jones, 

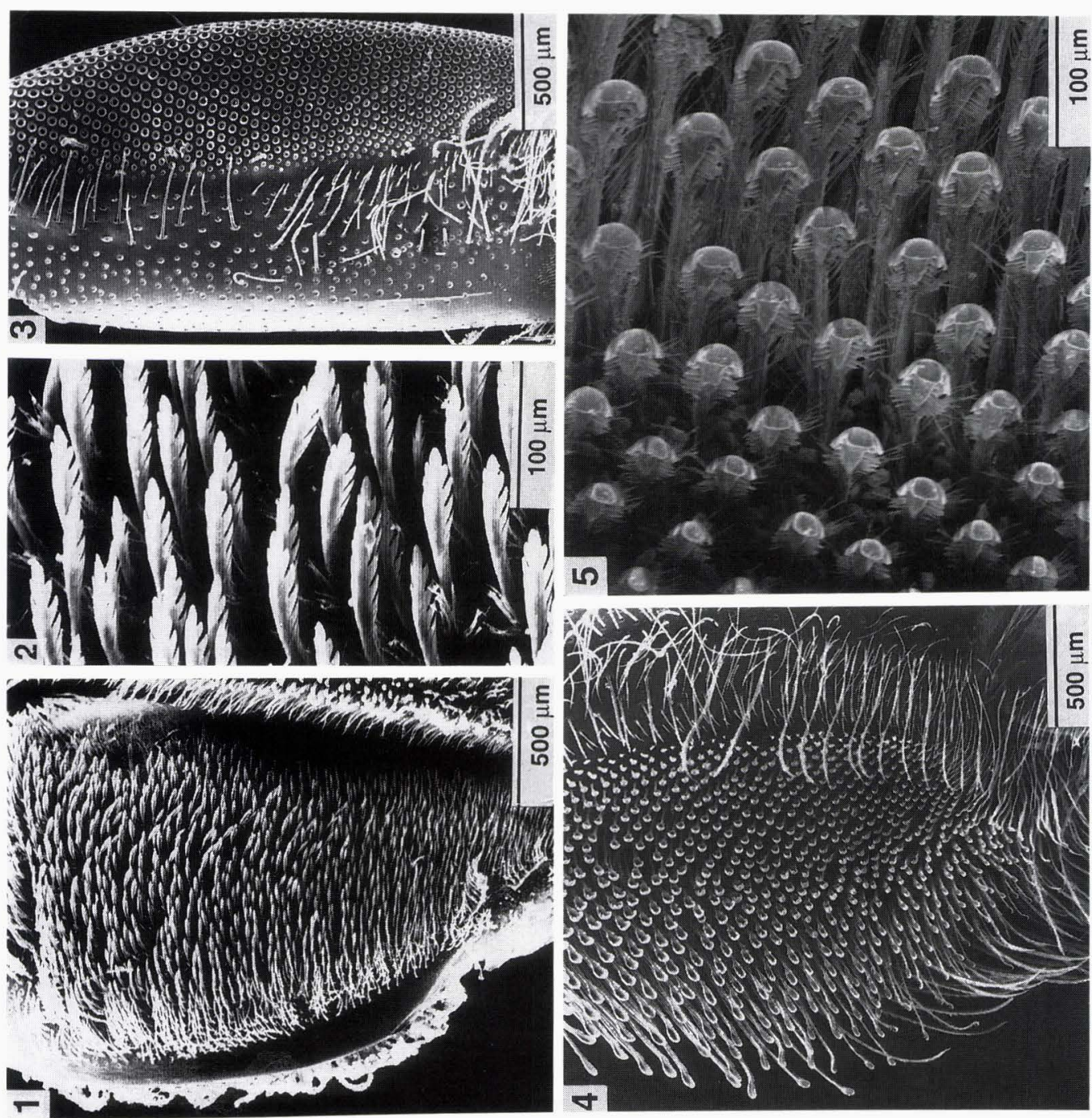

Fig. 1. Maxillipeds and setae of $U$. lactea. 1: Outer side of the merus of the first maxilliped of a male of $15.95 \mathrm{~mm} \mathrm{CW}$. 2: Arrow-head setae of the first maxilliped of the same male. 3: Inner side of the merus of the second maxilliped of a male of $10.8 \mathrm{~mm} \mathrm{CW}$. Setae were removed by sonication. 4: Inner side of the merus of the second maxilliped of a male of $14.25 \mathrm{~mm} \mathrm{CW}$, showing two kinds of spoon-tipped setae; long-stalked and short-stalked. Plumose setae cover less than half of the proximal area. 5: Spoon-tipped setae on the second maxilliped of a male of $18.3 \mathrm{~mm} \mathrm{CW}$; longstalked (right) and short stalked (left).

1978): short stalked and long stalked spoon-tipped setae, and plumose setae. The plumose setae grow on the proximal region of the lower half of the inner margin. Rows of small-sized short setae, occur near the center of the second maxilliped. An increase in length of the setae occurs from the central (peripheral) to proximal areas. However, there is no clear boundary separating the areas where short or long stalked setae occur. On the first maxillipeds, Ono (1965) reported two types of setae which could be discriminated by the shape of the arrow and the length of stalk. 


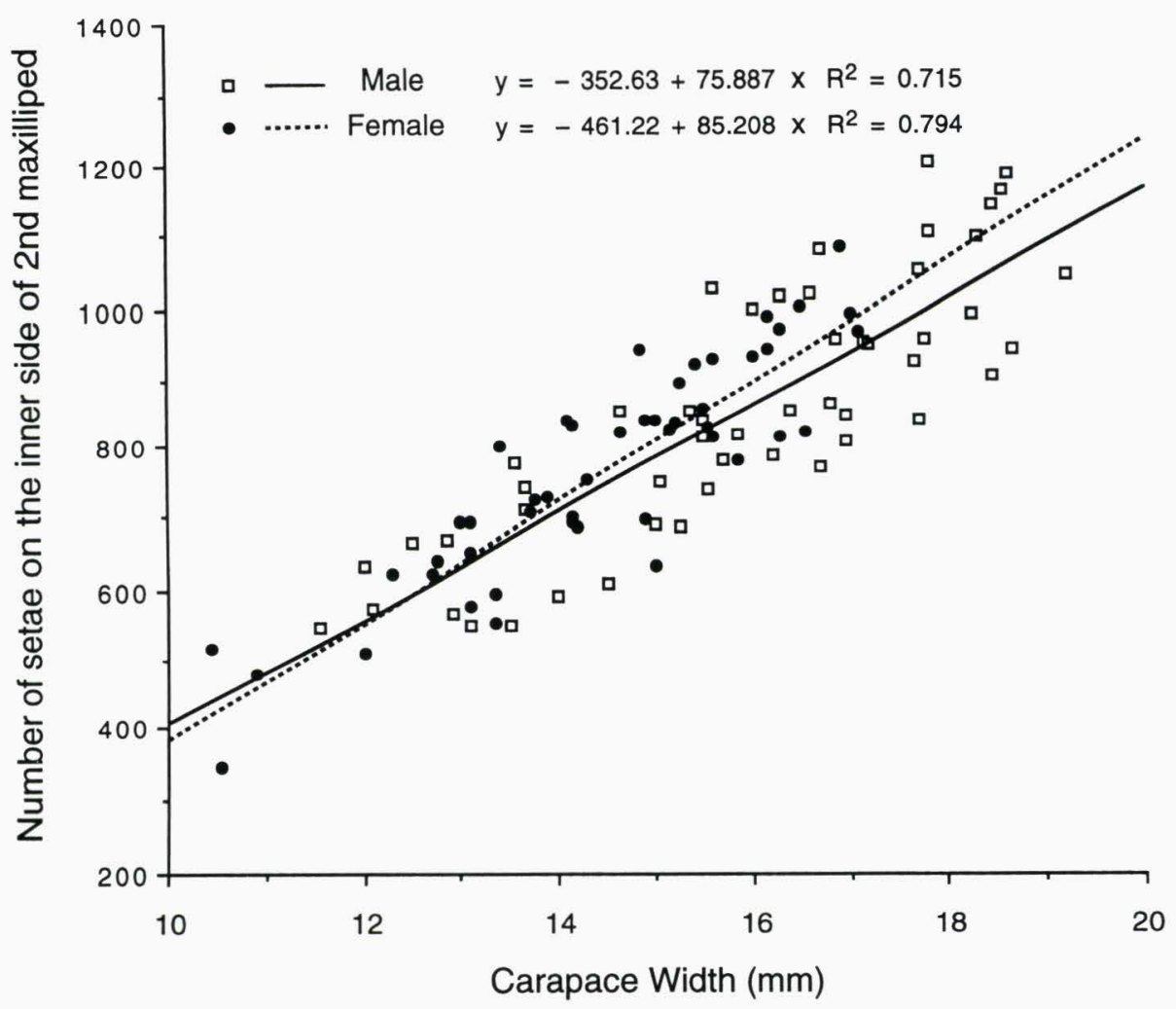

Fig. 2. The relationship between the number of spoon-tipped setae growing on the inner side of the merus of the second maxilliped and the carapace width of U. lactea.

However, in the present study we found that the morphological differences between the setae were not large enough to separate two types.

Number of setae on the second maxilliped

The relationship between the number of setae on the inner side of the second maxilliped merus and the crab size (maximum carapace width (CW)) (Fig. 2). All setae were counted. For a crab of $16 \mathrm{~mm}$ $\mathrm{CW}$, the total number of setae is estimated to be 858 for a male and 899 for a female. The value is somewhat larger for females, but, no significant difference was found between the sexes (ANCOVA, Fvalue $=3.157, \mathrm{P}=0.0787$ ).

To examine the size difference of the second maxilliped between the sexes, the maximum length and the maximum width of the merus of the second maxilliped were measured and plotted against the crab size (Fig. 3). There is no significant difference by the sex.

\section{First maxilliped}

The relationship between the setal number on the outer side of the merus of the first maxilliped and $\mathrm{CW}$ is shown in Fig. 4. There was no significant difference between the sexes in the number of arrow-head setae. Based upon the equations shown in Fig. 4, the numbers of setae on crabs of $16 \mathrm{~mm} \mathrm{CW}$, are estimated to be 2,764 in males and 2,724 in females respectively. The maximum length and width of the merus of the first maxilliped were measured under a stereo microscope and the results are summarized in Fig. 5. There was no significant difference be- 


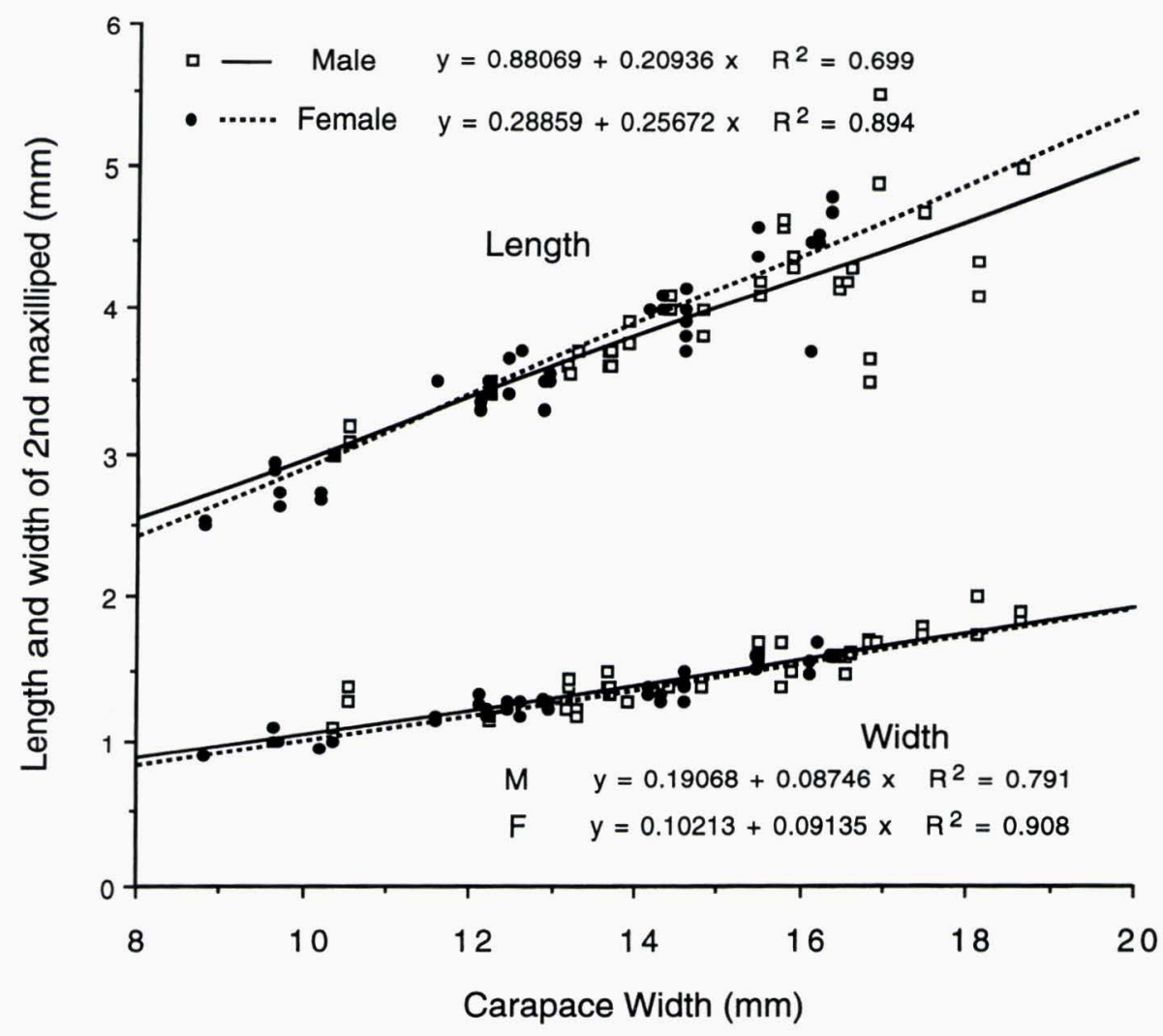

Fig. 3. The relationship between the length and width of the merus of the second maxilliped and the carapace width of $U$. lactea.

tween the sexes.

The relationship between the width of setae and crab size

To study the size of setae, we measured the maximum width of the spoontip of the setae at the centre of their distribution under a light microscope. The tips of setae were easily distorted during dehydration and were not suitable to measure with the scanning electron microscope. The width of the tip increased with crab size (Fig. 6). However, the size difference in tip between small and large crabs is not as great. The widths of setal tips of 6 and $16 \mathrm{~mm} \mathrm{CW}$ crabs estimated from the equations presented in Fig. 6 are 44 and $55 \mu$ in males and 43 and $57 \mu$ in females respectively. The $167 \%$ increase of CW only results in a $25 \%$ and $33 \%$ in- crease in setal size for males and females respectively.

We found no significant morphological differences in the first and second maxillipeds between males and females of $U$. lactea. Although there are individual differences, males and females of $U$. lactea have equally equipped mouthparts.

\section{Discussion}

Our conclusion on the numbers of setae on the first and second maxillipeds is different from that of Weissburg (1991). Part of the difference might be due to the difference in our methods. We counted all the setae on the outer side of the first maxilliped and the inner side of the second maxilliped. We reasoned that counts or examination of setae should be done on 


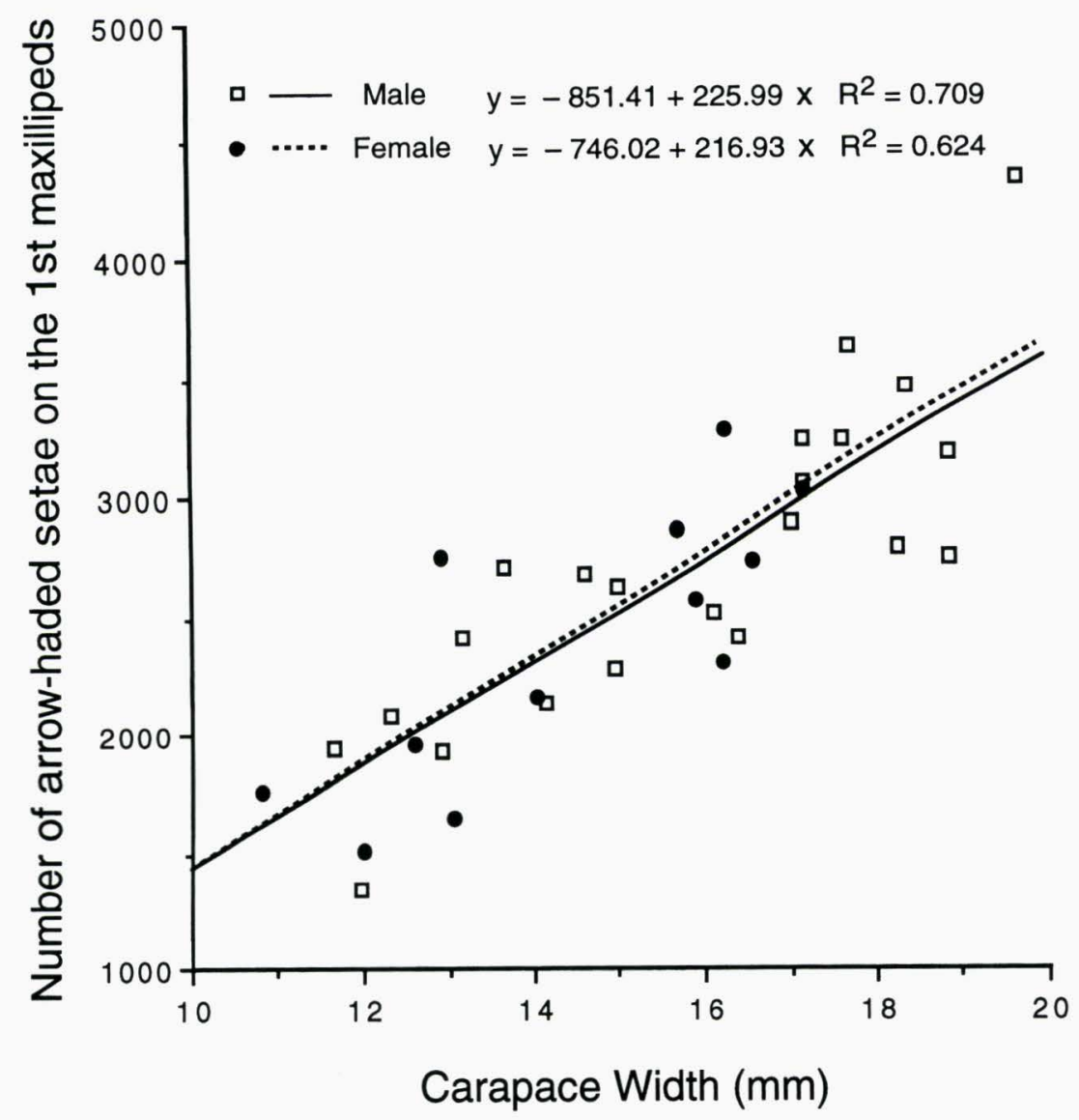

Fig. 4. The relationship between the number of arrow-headed setae on the outer side of the merus of the first maxilliped and the carapace width of $U$. lactea.

these sides of the mouthparts because the substratum carried to the buccal cavity is washed and scoured to separate food material from inorganic particles by the combined action of the setae on the inner side of the second and the outer side of the first maxillipeds (Miller, 1961; Bauchau \& Passelecq-Gérin, 1988). Therefore, the density of setae is high and the number is large on both sides. The mouthpart's surfaces on which Weissburg (1991) counted and examined setae contribute to a lesser degree to food sorting. Hence, the number and density of setae might be more variable compared to the other more important sides and some sexual differences might be apparent. Another portion of dif- ference might be attributed to interspecific differences. Uca lactea prefers sandy mud substrate and develops extensive spoon-shaped setae on the second maxillipeds (Ono. 1965).

Icely \& Jones (1978) studied the distribution of the Uca species on an East African shore and reported that $U$. lactea inhabits sandy areas with a larger particle size than is found in areas occupied by other Uca species. They described the function of the setae on the second maxilliped as follows: The setae on the second maxillipeds scour the coarser particles trapped on the first maxillipeds, and free organic matter is trapped on the first maxillipeds. The second maxillipeds of $U$. 


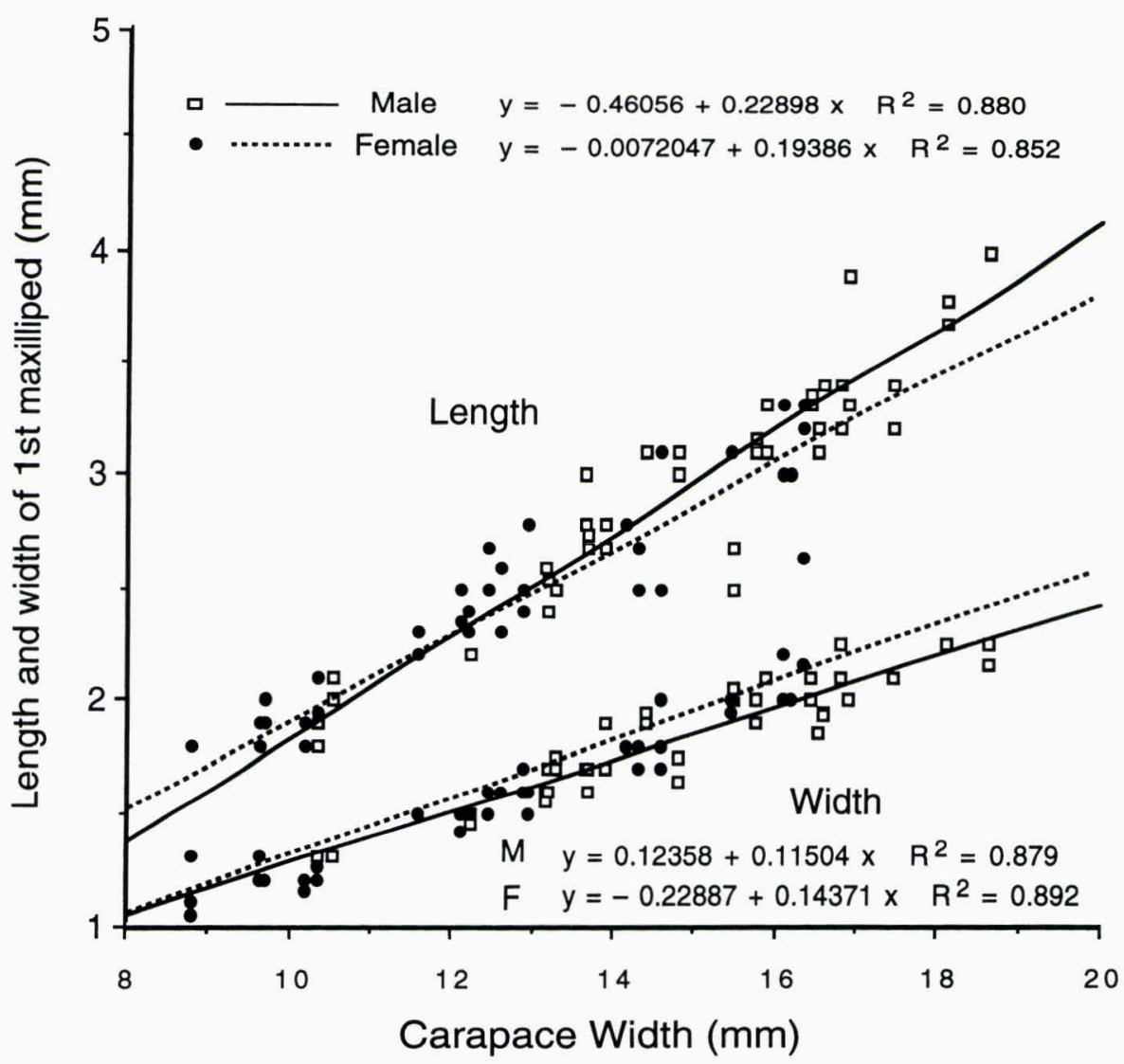

Fig. 5. The relationship between the length and width of the merus of the first maxilliped and the carapace width of $U$. lactea.

lactea are well adapted to cope with the high proportion of sand grains and large particles associated with its habitat. The scouring surface area provided by the spoon shaped setae is approximately twice that found in other species. The short stalked spoon setae are relatively inflexible and produce an even more efficient rasping action than the flexible long stalked spoon setae. Icely \& Jones (1978) noted that the short stalked spoon-shaped setae are only present in $U$. lactea. Robertson \& Newell (1982) studied the abilities of three fiddler crab species, $U$. pugilator, U. pugnax and U. minax to remove particle bound bacteria from sandy sediments. They found that $U$. pugilator removed twice as many attached bacteria than U. pugnax. Weissburg $(1991,1992)$ examined $U$. pugnax, which lives in muddy tidal flats in salt marshes, and found that the spoon-tipped setae are less numerous compared to $U$. pugilator (Miller, 1961). The lesser development in the ability to remove bacteria or food particles from the sediment in $U$. pugnax might be the result of differences in the density of setae between two sexes.

Altevogt (1955a, b) counted the scooping frequency in $U$. vocans and reported that it was 18 per 10 seconds in females and 15 in males. He suggested that males carry more substratum per scoop to the mouthparts than females. Valiela et al (1974) studied sexual differences in the feeding activities of $U$. pugnax and re- 


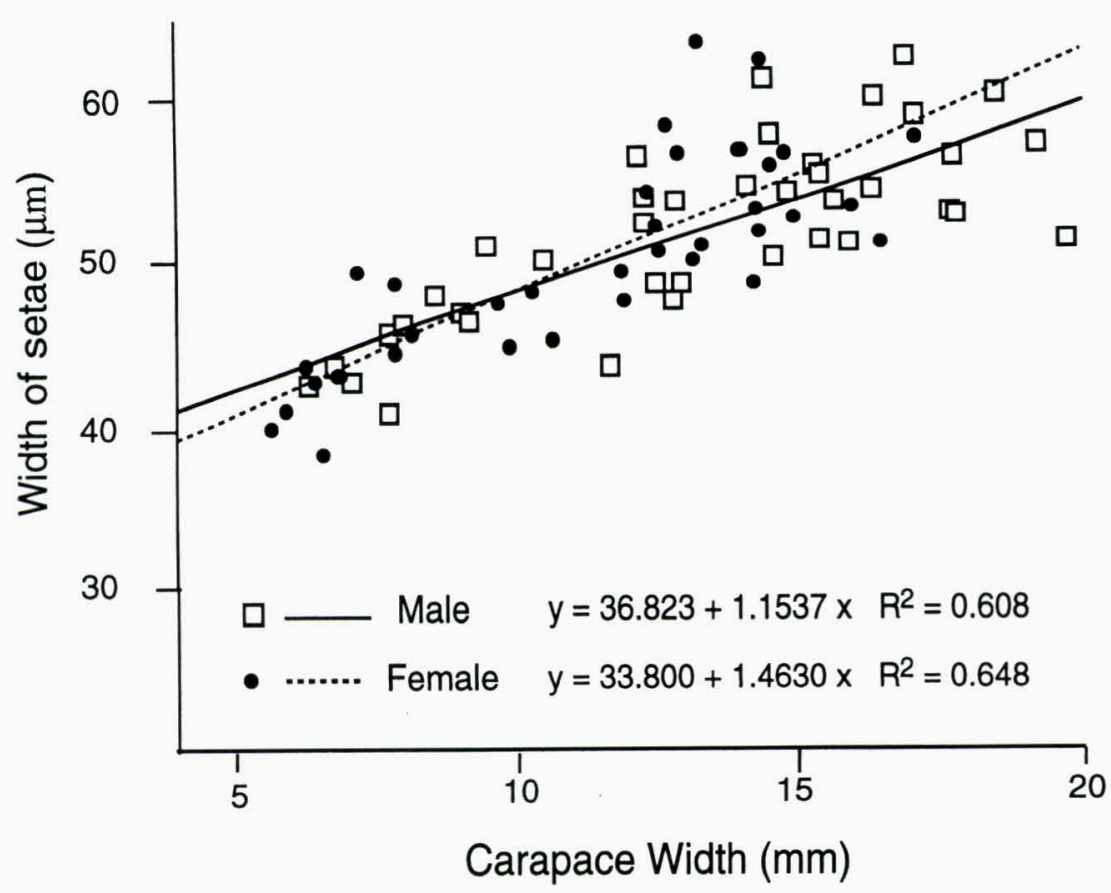

Fig. 6 . The relationship between width of the tips of setae on the second maxillipeds and carapace width of $U$. lactea.

ported that male crabs scoop sediments at about half the rate of females, but males compensate by feeding about twice as long. There are minimal differences in the food demands and digestive efficiencies between the sexes. Further compensation could be achieved by the slightly larger holding surface of the feeding chelae in males. Weissburg (1992) made a very detailed study of the feeding activities of $U$. pugnax. It was shown that the females feed faster than males but they made less effort when the concentration of food material is low. To compensate for their handicap in feeding, males scooped with a frequency only $20 \%$ less at the lowest food concentration compared to the highest concentration. At the higher concentration, females scooped with a frequency nearly twice that of males. It was suggested that for a given scoop rate females extract a higher amount from the sediment because their extraction apparatus must be more efficient in order to compensate for higher maximum scoop rates. Caravello \& Cameron (1987) found that male $U$. panacea compensate for their non-functional large chelipeds by increasing the rate at which they feed with their small chelipeds and by possessing a larger feeding chelae (relative to females). In this fashion, males maintain an energy intake equivalent to that of females.

In $U$. lactea, the duration of active hours each day was studied (Yamaguchi, 2000). It seemed a little longer in males than females, however, the difference was not significant. The frequency of scooping per minute in males is less compared to females (Yamaguchi, 2000). However, the difference, $55-57 \%$, is not so large as in $U$. pugnax. Males of $U$. lactea have $10 \%$ longer and wider feeding chela than those of females. The amount of substratum lifted per scoop by males is larger than by females. Therefore, no clear difference in 
the daily production of sand pellets by sexes was observed (Yamaguchi, 2000). Such differences in the feeding activities between the two species likely produced differences in the density and number of setae on the sides of the maxillipeds that Weissburg (1992) examined.

Altevogt (1955a, b) examined the width of spoon of the setae in $U$. vocans and $U$. annulipes. In 13 and $27 \mathrm{~mm} \mathrm{CW}$ crabs of $U$. vocans the width is 46 and $69 \mu$ respectively. In 8 and $15 \mathrm{~mm} \mathrm{CW}$ crabs of $U$. annulipes it is $32 \mu$ and $46 \mu$ respectively. His results agree with ours. The size of setae increases with CW, however, the growth is gradual. The setae are used to scrub food substances from sand particles. If there was a large increase or decrease of setal size with crab size, then we would expect it to be linked to a change of substrate preference with crab size. No such change was observed; crabs of all sizes live together and feed on the same sediment. Therefore, these morphological characteristics agree well with the expectation based on the distribution of the crabs in the habitat.

\section{Acknowledgement}

We wish to express our sincere thanks to Dr. John H. Christy of the Smithsonian Tropical Research Institute, for his kind reading and correction of the manuscript. We also thank Dr. Colin L. McLay of the University of Canterbury, for reviewing the manuscript.

\section{Literature cited}

Altevogt, R., 1955a. Beobachtungen und Untersuchungen an indischen Winkerkrabben. Zeitschrift für Morphologie und Ökologie Tiere, 43: 501522.

- $1955 \mathrm{~b}$. Some studies on two species of Indian fiddler crabs, Uca marionis nitidus (Dana) and $U$. annulipes (Latr.). Journal of the Bombay Natural History Society, 52: 1-15.

Bauchau, A. G., \& Passelecq-Gérin, E., 1988. Adaptive structures to filter-feeding in the sand crab Scopimera gordonae Serene and Moosa, 1981 (Crustacea Decapoda Brachyura Ocypodidae). Indo-Malayan Zoology, 5: 23-29.

Caravello, H. E. \& Cameron, G. N., 1987. The effects of sexual selection on the foraging behaviour of the Gulf Coast fiddler crab, Uca panacea. Animal Behaviour, 35: 18641874.

Crane, J., 1941. Eastern Pacific Expeditions of the New York Zoological Society. XXVI. Crabs of the genus Uca from the west coast of Central America. Zoologica, 26: 145-209, plates I-IX.

,- 1975 . Fiddler crabs of the world, Ocypodidae: Genus Uca. Princeton University Press, Princeton, New Jersey, i-xxiii. 1-736.

Icely, J. D., \& Jones, D. A., 1978. Factors affecting the distribution of the genus $U c a$ (Crustacea: Ocypodidae) on an East African shore. Estuarine and Coastal Marine Science, 6: 315-325.

Miller, D. C., 1961. The feeding mechanism of fiddler crabs, with ecological considerations of feeding adaptations. Zoologica, 46: 80-101.

Ono, Y., 1962. On the habitat preferences of ocypoid crabs I. Memoir of Faculty of Science, Kyushu University, Ser. E. (Biology), 3: 143-163.

-1965 . On the ecological distribution of ocypoid crabs in the estuary. Memoir of Faculty of Science, Kyushu University, Ser. E. (Biology), 4: 1-60. pls. 1-5.

Robertson, J. R., \& Newell, S. Y., 1982. A study of particle ingestion by three fiddler crab species foraging on sandy sediments. Journal of Experimental Marine Biology and Ecology, 65: 11-17.

Sakai, T., 1976. Crabs of Japan and the adjacent seas. Kodansha, Tokyo, i-xxix, 1-773.

Valiela, I., Babiec, D. F., Atherton, W., Seitzinger, S., \& Krebs, C., 1974. Some consequences of sexual dimorphism: Feeding in male and female fiddler crabs, $U c a$ pugnax (Smith). Biological Bulletin, 147: 652-660.

Weissburg, M., 1991. Morphological correlates of male claw asymmetry in the fiddler crab Uca pugnax (Smith) (Decapoda, Brachyura). Crustaceana, 61: 11-20.

-1992 . Functional analysis of fiddler crab foraging: sex-specific mechanics and constraints in Uca pugnax (Smith). Journal of Experimental Marine Biology and Ecology, 156: 105-124.

Yamaguchi, T., 1977. Studies on the handed- 
ness of the fiddler crab, Uca lactea. Biological Bulletin, 152: 424-436.

2000 (in press). Sexual differences in feeding by the fiddler crab, Uca lactea. Crustacean Research, 29: 121-132.
Addresses: (TY) Aitsu Marine Biological Station, Matsushima-cho, Amakusa-gun, Kumamoto 861-6102, Japan. (RO) Kumamoto Prefectural Fisheries Research Center, Oyano-machi, Amakusa-gun, Kumamoto 8613603, Japan. 